\title{
Fruit dispersal syndromes in animal disseminated plants at Tinigua National Park, Colombia
}

\author{
Síndromes de dispersión en plantas dispersadas por animales en el Parque Nacional \\ Tinigua, Colombia
}

\author{
ANDRÉS LINK ${ }^{1,2}$ \& PABLO R. STEVENSON ${ }^{3,4}$ \\ ${ }^{1}$ Departamento de Ciencias Biológicas, Universidad de Los Andes, Bogotá, Colombia. \\ Cr 1a No 18A-10, Bogotá, Colombia; e-mail: al898@nyu.edu \\ ${ }^{2}$ Current address: Doctoral Program in Physical Anthropology, New York University, \\ Rufus D. Smith Hall, 25 Waverly Place, New York, New York 10003-6790, USA \\ ${ }^{3}$ Doctoral Program in Anthropological Sciences, State University of New York at Stony Brook, New York, USA \\ ${ }^{4}$ Current address: Departamento de Ciencias Biológicas, Universidad de Los Andes, Bogotá, Colombia
}

\begin{abstract}
Fruit dispersal syndromes (groups of plants with similar fruit morphology, presumably adapted to dispersal by a particular set of vectors) have been described in a variety of tropical localities. In some cases the presence of different syndromes in each locality suggests independent evolution of fruit traits in response to selective pressures imposed by the particular animal community in each place. However, it is still unclear how general are fruit syndromes, and this is important to understand the evolution of mutualistic relationships. We compiled morphological information from about 500 fleshy fruited species at a lowland Neotropical forest in Tinigua National Park, Colombia, in an effort to test for the existence of fruit dispersal syndromes. We found that about two thirds of the plant genera analyzed could be classified in two different fruit types (large, protected, dull colored fruits, versus small, unprotected, bright colored fruits). These two syndromes correspond to the mammal and bird dispersal syndromes originally described at Cocha Cashu Biological Station, Peru. Two years of field observations on several fruiting plants revealed close associations between these fruit syndromes and the presumed animal dispersal vector. Our results support the idea that fruit dispersal syndromes are more general in Neotropical forests than previously inferred. However, we caution that similar syndromes found at Cocha Cashu and Tinigua may be a consequence of the floristic resemblance of both regions, and may not necessarily imply an independent case for the evolution of mammal and bird dispersal syndromes. Therefore, additional studies of fruit syndromes and biogeographical analyses would be necessary to assess how general are dispersal syndromes in the Neotropics.
\end{abstract}

Key words: fruit syndromes, fruit morphology, Neotropical forests, convergent evolution, frugivory.

\section{RESUMEN}

Los síndromes de dispersión de frutos han sido descritos para diferentes bosques tropicales. En algunos casos la presencia de diferentes síndromes de dispersión sugiere la evolución independiente de características morfológicas de los frutos como respuesta a presiones de selección particulares. Sin embargo, hasta el momento hay evidencias contrastantes sobre qué tan generales son estos síndromes. Este estudio reúne la información morfológica de aproximadamente 500 especies de plantas con frutos carnosos, en el Parque Nacional Tinigua, Colombia, en un esfuerzo por encontrar síndromes de dispersión de semillas. Alrededor de dos tercios de los géneros de plantas analizados se pueden agrupar en dos categorías: (frutos grandes, con protección y colores opacos; y frutos pequeños, sin protección y de colores llamativos), que corresponden a los síndromes de dispersión por mamíferos y aves descritos por Janson (1983) en Cocha Cashu, Perú. Nuestros resultados apoyan la idea que los síndromes de dispersión endozoocórica son más generalizados de lo que se había planteado anteriormente. Consideramos que la similitud en los resultados obtenidos en este estudio y en el Perú no necesariamente implica evolución independiente de los síndromes de dispersión, porque las floras de estos lugares son bastante similares. Por lo tanto, más estudios de este tipo son necesarios para entender mejor qué tan generales son los síndromes de dispersión en bosques Neotropicales.

Palabras clave: síndromes de dispersión, morfología de frutos, bosques Neotropicales, evolución convergente, frugivoría. 


\section{INTRODUCTION}

The process of seed dispersal by frugivores is a common interaction in almost every ecosystem and involves a large number of animal and plant species (Ridley 1930, Pijl 1972). For example, Neotropical rainforests animals disperse seeds of $50 \%$ to $90 \%$ of the plant species (Gentry 1988, Chapman 1995, Voss \& Emmons 1996). The close ecological relationships that exist among some plant and animal species suggest that they have been subject to mutual selective pressures in the past (Janzen 1983). However, no specialized relationships, as required for species-to-species coevolution (Thompson 1994), have been convincingly documented in seed dispersal systems (Witmer \& Cheke 1991).

Recent studies suggest that there are constraints on the evolution of fruit morphology (Howe 1984, Herrera 1985, 1986, Wheelwright 1988), and that dispersal systems have evolved mainly by diffuse coevolutionary processes (Janson 1983, Janzen 1983, Herrera 1985). First of all, different selective forces may act in every stage of a plant's life cycle (Schupp 1995) and this complex web of potential forces may limit co-evolutionary trends between plants and frugivores. Furthermore, other studies have shown that fruit shape could be associated with phylogenetic inertia and developmental constraints (Jordano 1995). Finally, some authors emphasize low heritability for the evolution of fruit traits (i.e., Obeso 1993). Consequently, diffuse coevolution is now considered as the main process affecting seed dispersal systems. This type of evolution might have produced different dispersal syndromes or associated morphological traits that could have evolved independently as adaptations for a particular seed disperser agent (Pijl 1972, Janson 1983).

Dispersal syndromes have been defined for groups of plant species with similar seed dispersal strategies, and the most general strategies involve completely different dispersal agents (Ridley 1930, Pij1 1972). For example, in a Peruvian rainforest, Janson (1983) found associations among three morphological fruit characters: size, color, and protection. Two-thirds of the fruits had one of two character complexes matching the morphological characteristics of mammals and birds. In particular, large, dull colored fruits (orange, yellow, brown or green) with a husk, were associated with primate dispersal, while small, bright colored fruits (red, black, white, blue, purple, or with mixed colors), without a husk, seemed suitable for bird dispersal. However, the generality of these two dispersal syndromes for tropical forests remains to be demonstrated.

Gauthier-Hion et al. (1984) found one syndrome for bird and primate fruits in an African forest and a second syndrome for seed dispersal by other mammal species. Fruits dispersed by birds and primates were associated with no pre-dispersal predation; yellow, orange, red or violet colors; less than $50 \mathrm{~g}$, and succulent arils with soft or no protection. In contrast, fruits dispersed by ungulates, rodents, and elephants had predispersal predation; green or brown colors; more than $50 \mathrm{~g}$; fibrous or dry pulp and strong protection. Although, their results differ from Janson's, they support the idea of a syndrome generated by interaction with frugivores that do not occur in the Neotropics. Fisher \& Chapman (1993) compiled data on fruit dispersal syndromes from five different tropical sites and found few fruit character associations (i.e., between color and protection). They also found that the flora of New Guinea has a good representation of large, protected fruits, which elsewhere have been associated with primate dispersal, despite the lack of evidence of primate occupation of the island in the past. It is known that the largest fruits in New Guinea are consumed by cassowaries, hornbills, and flying foxes ${ }^{1}$, but without knowledge of their dispersal efficiency, it is difficult to predict which fruit syndromes might have evolved in the island and to validate New Guinea's data as evidence of uncoupled diffuse coevolutionary paths. Interestingly, in a different region with a reduced number of seed dispersers, a particular mistletoe species in the Loranthaceae (a family characterized by colorful fruits dispersed by birds) has green fruits and is exclusively dispersed by a marsupial (Amico \& Aizen 2000). This study again suggests that different fruit syndromes might evolve in response to particular dispersal agents.

Fruit syndromes have been analyzed using a variety of methods (i.e., Knight \& Siegfried 1983, Dowsett-Lemaire 1986), which is an additional problem to assess how widespread are they. For example, Fisher \& Chapman (1993), excluded fruits with mixed colors from their analyses and these methodological differences might explain some contrasts found

\footnotetext{
${ }^{1}$ MACK A \& D WRIGHT (2002) The frugivore community and the fruiting plant flora in a New Guinea rainforest. Tropical Forest: Past, Present, Future: 69pp. Annual Meeting of the Association for Tropical Biology, Panamá City, Panamá.
} 
when comparing fruit syndromes among tropical sites.

The main purpose of this work was to assess dispersal syndromes in the flora of Tinigua National Park, Colombia. Furthermore, we wanted to verify whether fruits classified in a particular morphological syndrome were actually visited preferentially by the same group of seed dispersers predicted to be associated with the syndrome. Although our results documented two main dispersal syndromes coincident with Janson (1983), we suggest that further studies are necessary to evaluate the general occurrence of these dispersal syndromes in Neotropical forests.

\section{MATERIAL AND METHODS}

\section{Study area}

This study was conducted at the CIEM (Centro de Investigaciones Ecológicas Macarena), a tropical rain forest in the northwestern Amazon, between the eastern Andes and Sierra de la Macarena, in the Departamento del Meta, Colombia. The CIEM is located on the right margin of Río Duda (2 $2^{\circ} 40^{\prime} \mathrm{N}, 74^{\circ} 10^{\prime} \mathrm{W}$; 350$400 \mathrm{~m}$ of altitude) about $13 \mathrm{~km}$ before it reaches the Río Guayabero, and it is part of Parque Nacional Tinigua (Stevenson et al. 1994). Mean annual temperature is around $26{ }^{\circ} \mathrm{C}$, and is relatively constant throughout the year. Precipitation varies between 2,600-2,800 mm annually, with a dry season between December and March and a rainy season between April and November; peak rainfall occurs in June and July (Kimura et al. 1995, Stevenson 2002). There are six basic vegetation types: mature terra firme forest, open canopy terra firme forest, two types of lowland seasonally flooded forest, secondary forest and riparian forest (Hirabuki 1990, Stevenson 2002).

A total of 445 bird species have been recorded at CIEM (Cadena et al. 2000). Many are frugivorous or eat fruits as part of their diet. Curassows, toucans, trogons, parrots, tanagers, manakins, woodpeckers, thrushes and other birds eat fruit regularly. There are seven primate species at the study site: Ateles belzebuth, Lagothrix lagothricha, Allouata seniculus, Cebus apella, Saimiri sciureus, Callicebus cupreus and Aotus brumbacki (see Stevenson 2002). All of them eat fruits as part of their diets. There are several other fruit-eating mammals at the CIEM including tayras (Eira barbara), tapirs (Tapirus terrestris) and some of the 34 bat species reported at the site (Rojas 1997).

\section{Field protocols}

We classified fleshy fruits into bird and mammal-dispersed classes following Janson (1983). We selected the plants collected at the CIEM (Stevenson et al. 2000, Stevenson unpublished data) that have fleshy fruits, or can potentially offer a food source to frugivores. Morphological information was taken mainly from the fruit guide of the study site (Stevenson et al. 2000). We made additional fruit measurements in the field during the study period (November 1999-July 2001), and used information from a guide to the fruits of Guyana (Roosmalen 1985). For each plant species with fleshy fruits we recorded its fruit size, color, and protection. Fruit size was either small or large. Fruit size was considered as the smaller dimension between its width and length. Large fruits are those that have a larger dimension than the average fruit size of all the plant species in this study. For capsular fruits, because the capsule is not manipulated by frugivores, we only considered the size of the seeds and fleshy pulp.

We considered the following color categories: red, white, black, blue/purple, green, yellow, brown, orange and mixed colors. A mixed color fruit has at least two different colors when ripe, including its supporting structures. The third morphological character was the presence or absence of protection. Protected fruits were those that presented a distinct hard, non-nutritious layer as a barrier to feeding. Fruits with a soft, flexible skin covering at least $10 \%$ of the external fruit dimension were also considered protected. Otherwise fruits were considered unprotected.

Some studies of the evolution seed dispersal and fruit morphology often focused on the species level, without considering its consequences (see Fischer \& Chapman 1993). This may overestimate the number of evolutionary events that led from an ancestral to a derived character (Lord et al. 1995), because phylogenetically related species are not independent unities (Harvey \& Pagel 1991). In our study, we used genera as the taxonomic unit to determine the existence of associations between fruit characters (Janson 1983, 1992). We distinguished monomorphic genera (those with only one combination of fruit characters) from polymorphic ones. Each monomorphic genus was considered a basic morphological unit (BMU), and each set of species within a polymorphic genus sharing the same fruit characters was also considered a BMU. 
For monomorphic genera, we calculated the percentage of protected genera in each fruit color category. We tested heterogeneity and subset homogeneity (Sokal \& Rohlf 1995) to group different color fruits according to their percentage of protection. Afterwards, we tested heterogeneity within each of the subgroups or types obtained. Polymorphic genera were assigned to color groups derived from monomorphic genera analysis. A $\chi^{2}$ test was used to determine association between fruit color and protection.

Color categories were the following: type A, low percentage of protection and bright colors (white, red, blue, black and mixed colors), and type $\mathrm{B}$, high percentage of protected genera and dull colors (orange, green, yellow and brown). We used a Kolmogorov-Smirnov test to assess differences in fruit size between type $\mathrm{A}(\mathrm{n}=$ $300)$ and type B $(n=191)$ fruits. We performed this test at the species level, because fruit size varies considerably between polymorphic and monomorphic genera.

All genera were classified dichotomously by size, color and protection which yielded eight possible combinations. We used a G-test of independence (Sokal \& Rohlf 1995) to determine associations among fruit traits.

For the BMU having character complexes associated with fruit dispersal by mammals (large, type B color and protected) or birds (small, type A color and unprotected) (Pijl 1972, Janson 1983), we obtained information on visits by frugivores. This information was gathered from previous studies at the CIEM, especially for primates and birds (see Stevenson et al. 2000 and references therein). Observations on more than 75 plant species for more than $3,438 \mathrm{~h}$ were carried out to corroborate whether species with a particular syndrome were actually visited by the predicted seed dispersal vector. These observations were conducted mostly between 06:00 and 10:00 $\mathrm{h}$ and between 15:00 and 18:00, from a point of good visibility on the ground. Seed removal by nocturnal animals was checked only indirectly (using fruit traps) for a smaller set of plant species $(n=5)$.

\section{RESULTS}

We examined 491 plant species, corresponding to $80 \%$ of the fleshy-fruited plants found at the study site. Fruit characters are described in Appendix 1. We found an association between fruit protection and color (Fig. 1). We found heterogeneity in the percentage of protected monomorphic genera $(n=197)$ in each color category $\left(\chi^{2}{ }_{(8)}=51.5, \mathrm{P}<0.001\right)$, but subgroups within each type were homogeneous [type A: $\left(\chi^{2}{ }_{(4)}=4.30, \mathrm{P}>0.05\right.$; type B: $\chi^{2}{ }_{(3)}$ $=3.93, \mathrm{P}>0.05)]$. Type $\mathrm{A}$ and type $\mathrm{B}$ color fruits showed differences in the proportion of protected genera $\left(\mathrm{G}_{\mathrm{H}}=49.4, \mathrm{P}<0.001\right)$. Because of the small number of polymorphic genera, we grouped them in type A and type B colors. Fifteen out of the 40 polymorphic genera were grouped in one color category. Of the remaining 25 polymorphic genera, 23 varied in color and two in protection. No genus varied in both traits. From the 23 polymorphic genera, five out of eight protected BMUs are of type $\mathrm{B}$ color and 22 out of the 53 unprotected BMUs are of type $\mathrm{B}$ color, yielding no statistical association $\left(\chi_{(1)}^{2}=0.53, \mathrm{P}>0.05\right)$. In the two genera that vary in protection, one of two protected BMU are type B color $\left(\chi^{2}{ }_{(1)}=0\right.$, $\mathrm{P}>0.05)$ and have no significant association between color and protection.

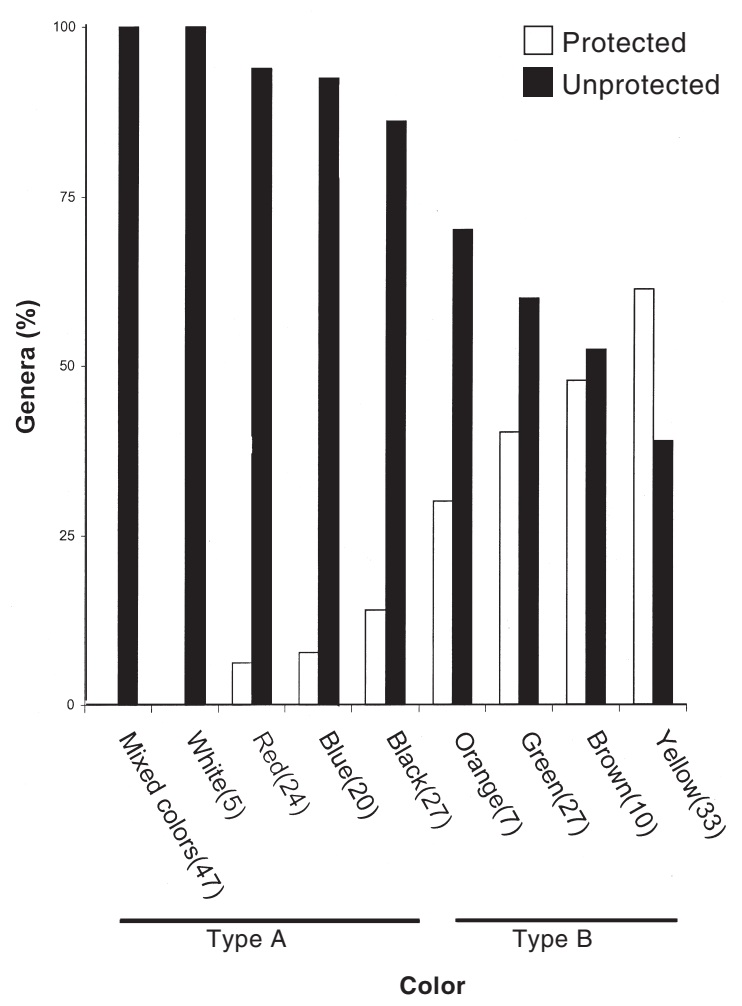

Fig. 1: Percentage of protected and unprotected fruits iby different color categories in the flora of Parque Nacional Tinigua, Colombia. The number of monomorphic genera is shown in parenthesis.

Porcentaje de frutos protegidos y sin protección en las diferentes categorías de color, en la flora del Parque Nacional Tinigua, Colombia. Los números en paréntesis corresponden al número de géneros monomórficos. 
We found differences in the size distribution between type A and type B fruits (KolmogorovSmirnov test $\mathrm{D}=0.507, \mathrm{n}=491, \mathrm{P}<0.001)$ (Fig. 2). Average fruit size was $17.3 \mathrm{~mm}$ (range $1-200 \mathrm{~mm}, \mathrm{n}=491)$. Average size of type A fruits was $11.4 \mathrm{~mm}$ on average $(\mathrm{n}=300)$, with $87 \%$ of them smaller than the average size of all the fruits analyzed, while type B were $27.2 \mathrm{~mm}$ on average $(\mathrm{n}=191)$ and $62 \%$ were larger than the overall average. Almost $65 \%$ of all BMUs $(n=299)$ analyzed here belonged either to large, type B and protected or small, type A and unprotected fruits (Table 1). These two character complexes corresponded closely to the fruit morphology of primates and bird dispersal syndromes (Pijl 1972, Janson 1983). The hypothesis of independence between fruit traits was rejected for the three fruit traits considered in this study $\left(\mathrm{G}_{(4)}=165.5, \mathrm{P}<0.001\right)$ and for each combination any two characters: color and protection $\left(\mathrm{G}_{(1)}=53.4, \mathrm{P}<0.001\right)$; color and size $\left(G_{(1)}=70.1, P<0.001\right)$; size and protection $\left(\mathrm{G}_{(1)}=80.6, \mathrm{P}<0.001\right)$.

Out of 299 BMUs, 193 have fruit character complexes associated with either bird $(n=150)$ or primate dispersal $(n=43)$. We observed birds (excluding parrots) eating fruits of 84 BMUs; 76 of them corresponding to type A fruits. Primates were observed eating 83 BMUs; 53 of them corresponding to type B fruits. There was a significant association between the type of disperser (bird or primate) and fruit morphology (Aves: $\chi_{(1)}^{2}=7.2, \mathrm{P}<$ 0.05; Primates: $\left.\chi_{(1)}^{2}=8.4, \mathrm{P}<0.05\right)$.

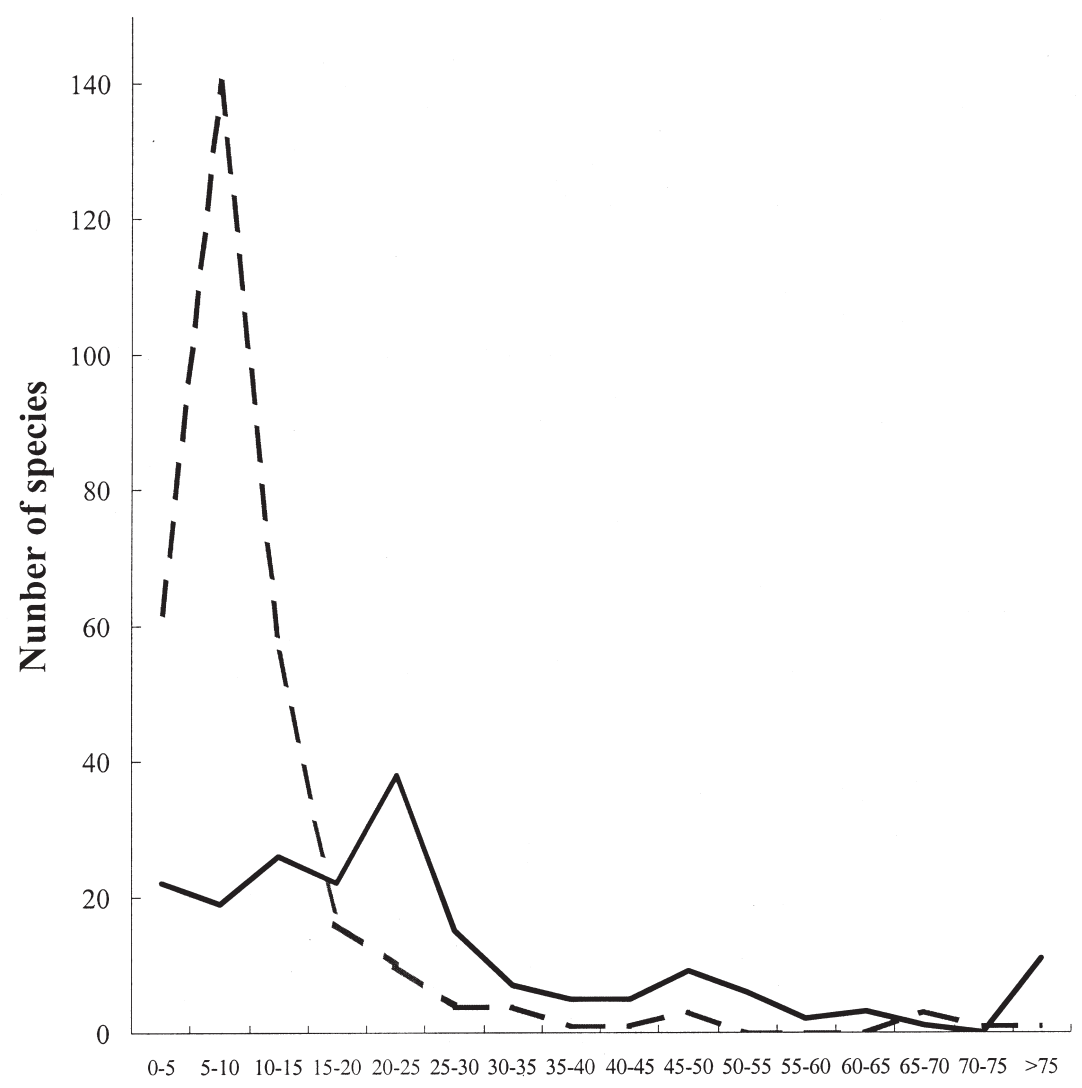

Fruit size (mm)

Fig. 2: Fruit size distribution for type A (non-protected and with bright colors) and type B fruits (protected and with dull colors) at Tinigua National Park. The dashed line represents type A fruits and the continuous line represents type B fruits.

Distribución del tamaño de los frutos de tipo A (sin protección y con colores vistosos) y tipo B (protegidos y con colores opacos) en el Parque Tinigua. La línea punteada corresponde a los frutos de tipo A, mientras que la línea continua corresponde a los frutos de tipo B. 


\section{TABLE 1}

Distribution of BMUs (morphological basic units) into eight possible combinations of three fruit characters (fruit size, color, and protection) for animal dispersed plants at Tinigua National Park, Colombia. Type A and type B colors described in the text. Numbers in parenthesis are expected values assuming independence of characters.

Distribución de BMUs (unidades morfológicas básicas) en las ocho posibles combinaciones de tres caracteres morfológicos de los frutos (tamaño, color y grado de protección), para las plantas dispersadas por animales en el Parque Tinigua, Colombia. Los números en paréntesis corresponden a los valores esperados asumiendo independencia entre los caracteres

\begin{tabular}{lccccc}
\hline Size & \multicolumn{2}{c}{ Type A color } & & \multicolumn{2}{c}{ Type B color } \\
\cline { 2 - 3 } \cline { 5 - 6 } & Protected & Unprotected & & Protected & Unprotected \\
\hline$>17.3 \mathrm{~mm}$ & $7(12.5)$ & $22(49.7)$ & & $43(7.8)$ & $29(31.0)$ \\
$<17.3 \mathrm{~mm}$ & $5(24.4)$ & $150(97.4)$ & & $5(15.3)$ & $38(60.4)$ \\
\hline
\end{tabular}

\section{DISCUSSION}

The main result of this study at Tinigua is that fruit traits such as color, size, and protection are associated with the previously described bird and mammal dispersal syndromes (Ridley 1930, Pijl 1972, Janson 1983). Further, this relationship partly agrees with the use of fruits by the corresponding frugivore vectors. We found that very few bird species (some parrots, curassows, corvids and icterids) consume fruits with the primate dispersal syndrome as the size and protection of these fruits acts as a barrier to access its pulp and seeds. Nevertheless, monkeys frequently consumed fruits with the bird syndrome, and for no plant species did we find good evidence of relying on only one frugivores species for its fruit removal and dispersal. The complex web of interactions between frugivores and plants, including interactions between phylogenetically unrelated taxa do not fit the models of species-to-species coevolutionary process (Thompson 1994). Therefore, diffuse coevolution seems the most likely path for the evolution of these systems, although other non-evolutionary fortuitous events may also have a place. For example, under certain circumstances plant-frugivore interactions can be ecologically strong in spite of the lack of evolutionary history. In particular, the artificial introduction of plant species to new habitats has revealed that local frugivores are able to consume fruits never seen before, resulting in strong plant-animal interactions without evolutionary history (Herrera 1985). Thus, in the absence of a fossil record that could confirm strong interactions in the past, we are limited to describing the products of evolution and speculating about their potential origins.

Reciprocal evolution between birds and type A fruits seem to be more difficult than that between primates and type B fruits. Because of morphological constraints, many birds in Neotropical rainforests are unable to eat fruits that are either large or have a husk (Wheelwright 1985, Peres \& Roosmalen 2002). Only few guilds (i.e., parrots, crows, and icterids) have the ability to manipulate fruits with their feet, breaking up the fruit's husk rather than swallowing the whole fruit. Thus, if the seeds are more efficiently dispersed by primates than by birds, it is likely that plants could evolve husks to limit bird access to the fruit pulp. On the other hand, primates do not have morphological limitations to exploit the majority of fruits in the forest and this seems to be the reason why they exploit both type A fruits and type B fruits. Therefore, even if primates are not very efficient dispersers compared to birds, it would be difficult for plants to evolve morphological adaptations to limit the access of primates. It is possible that plants have used other means to deter fruit consumption by primates, such as chemical composition of fruits. For example, it is known that some families (i.e., Solanaceae) that are predominantly dispersed by bats and birds contain high quantities of secondary compounds in the pulp (Chipollini \& Levey 1997b). One of the hypotheses to explain the presence of these compounds in the pulp of fruits is the selection of particular seed dispersal agents (Chipollini \& Levey 1997a), and we believe that the inclusion of nutritional analyses could reveal additional fruit dispersal syndromes. 
The results about the association of fruit character complexes with particular groups of frugivores, are very similar to those reported by Janson (1983) in the Peruvian rainforest at Cocha Cashu. Both studies found associations between the size, color and presence or absence of protection. At Tinigua and Cocha Cashu, respectively, $65 \%$ and $66 \%$ of the fleshy fruits analyzed are either small, type A colors without a husk; or large, type B colors with a husk. Further, at both sites associations were found between the fruit character complexes and the dispersal agents. Primates and birds tend to consume preferentially those fruits assigned to their particular dispersal syndromes (Pijl 1972, Janson 1983). These results suggest that the primate and bird dispersal syndromes are more general in Neotropical communities than previously inferred (see Fisher \& Chapman 1993). However, one possible explanation for this finding could be the similarity in plant and animal assemblages between sites. At least 37 $\%$ of the plant species present at Tinigua occur also at Cocha Cashu and this was the second highest percentage of similarity among 18 Neotropical localities compared with the Tinigua flora (Stevenson \& Castellanos unpublished data). Animal composition is also very similar, especially birds and mammals. For example, frugivores represent a significant proportion of animal biomass, and primates, tapirs, and peccaries are the most important components at both sites (Terborgh 1983, Stevenson 1996, 2002). The avifauna is also very similar between these sites and the frugivore guild makes up a considerable fraction of avian biomass (Terborgh et al. 1990, Cadena et al. 2000), especially represented by few families such as curassows, tinamous, toucans, trogons and others. This suggests that a great proportion of the avian biomass, at both sites, have fruits as an important item of their diets. Other families of avian frugivores are diverse at these sites, like tanagers and manakins (Terborgh et al. 1990, Cadena et al. 2000). These results confirm the general similarities reported previously for the fauna and flora of western Amazonian forests (Gentry 1988, Voss \& Emmons 1996). In summary, at this point it is difficult to argue that the presence of primate and bird dispersal syndromes at both sites was either the result of similar evolutionary histories or of independent evolution driven by similar dispersers. For two Neotropical sites included in Fisher \& Chapman's (1993) study, only one showed a significant association of fruit characters corresponding to dispersal syndromes, therefore more studies of this type for a variety of vegetation types could help to clarify whether bird and primate dispersal syndromes are of general occurrence in Neotropical forests.

\section{ACKNOWLEDGEMENTS}

We thank Carolina Garcia, Mabel Suescún, Alicia Medina, Alejandro Franco and Gabriela de Luna for their assistance in the field. C.H. Janson, M.C. Castellanos, A. DiFiore, C. Mejia, and two anonymous reviewers made helpful comments. The Colombo-Japan agreement through $\mathrm{K}$. Izawa and C. Mejia allowed us to work at the CIEM, and the staff from Unidad de Parques del Ministerio del Medio Ambiente collaborated with logistical support and permissions. We are grateful to the local community of "El Tapir". Financial support was funded by Banco de La República, Primate Conservation Inc., Lincoln Park Zoo, Margot Marsh, Idea Wild, and Colciencias.

\section{LITERATURE CITED}

AMICO G \& MA AIZEN (2000) Mistletoe seed dispersal by a marsupial. Nature 408: 929-930.

CADENA D, M ÁLVAREZ, JM PARRA, I JIMÉNEZ, CA MEJÍA, M SANTAMARÍA, AM FRANCO, CA BOTERO, CD MEJÍA, AM UMAÑA, A CALIXTO, J ALDANA \& GA LONDOÑO (2000) The birds of CIEM, Tinigua National Park, Colombia: an overview of thirteen years of ornithological research. Cotinga 13: 46-54.

CHAPMAN CA (1995) Primate seed dispersal: coevolution and conservation implications. Evolutionary Anthropology 4: 74-82.

CIPOLLINI ML \& DJ LEVEY (1997a) Secondary metabolites of fleshy vertebrate-dispersed fruits: adaptive hypotheses and implications for seed dispersal. American Naturalist 150: 346-372.

CIPOLLINI ML \& DJ LEVEY (1997b) Why are some fruits toxic? Glycoalkaloids in Solanum and fruit choice by vertebrates. Ecology 78: 782-798.

DOWSETT-LEMAIRE F (1986) Frugivory and seed dispersal by birds and mammals in the afromontane forest of Malawi. Ibis 128: 168-169.

FISHER KE \& CA CHAPMAN (1993) Frugivores and fruit syndromes: differences in patterns at the genus and species level. Oikos 66: 472-482.

FLEMING TH (1981) Fecundity, fruiting pattern, and seed dispersal in Piper amalago (Piperaceae), a batdispersed tropical shrub. Oecologia 51: 42-46.

GAUTIER-HION A, JM DUPLANTIER, R QURIS, F FEER, C SOURD, JP DECOUX, G DOUBOST, L EMMONS, C ERARD, P HECKETSWEILER, A MOUNGAZI, C ROSSILHON \& JM THIOLLAY (1985) Fruit characters as a basis of fruit choice and seed dispersal in a tropical forest vertebrate community. Oecologia 65: 324-337.

GENTRY AH (1988) Changes in plant community diversity and floristic composition on 
environmental and geographical gradients. Annals of the Missouri Botanical Garden 75: 1-34.

HARVEY PH \& MD PAGEL (1991) The comparative method in evolutionary biology. Oxford University Press, Oxford, United Kingdom. viii+ 239 pp.

HERRERA CM (1985) Determinants of plant-animal coevolution: the case of mutualistic dispersal of seeds by vertebrates. Oikos 44: 132-141.

HERRERA CM (1986) Vertebrate-dispersed plants: why they don't behave the way they should. In: Estrada A \& TH Fleming (eds) Frugivores and seed dispersal: 5-18. Dr. W. Junk Publishers, Dordrecht, The Netherlands

HIRABUKI Y (1990) Vegetation and landform structure in the study area of La Macarena: a physiognomic investigation. Field Studies of New World Monkeys, La Macarena, Colombia 3: 35-48.

HOWE HF (1984) Constraints on the evolution of mutualisms. American Naturalist 123: 764-777.

JANSON CH (1983) Adaptation of fruit morphology to dispersal agents in a Neotropical forest. Science 219: 187-189.

JANSON CH (1992) Measuring evolutionary constraints: a Markov model for phylogenetic transitions among seed dispersal syndromes. Evolution 46: 136-158.

JANZEN DH (1983) Dispersal of seeds by vertebrate guts. In: Futuyma DJ \& M Slatkin (eds) Coevolution: 232-262. Sinauer, Sunderland, Massachusetts, USA.

JORDANO P (1995) Angiosperm fleshy fruits and seed dispersers: a comparative analysis of adaptation and constraints in plant-animal interactions. American Naturalist 145: 163-191.

KIMURA K, A NISHIMURA, K IZAWA \& CA MEJIA (1994) Annual changes of rainfall and temperature in the tropical seasonal forest at La Macarena Field Station Colombia. Field Studies of New World Monkeys. La Macarena, Colombia 9: 1-3.

KNIGHT RS \& WR SIEGFRIED (1983) Interrelationships between type, size and color of fruits and dispersal in Southern African trees. Oecologia 56: 405-412.

LORD J, M WESTOBY \& M LEISHMAN (1995) Seed size and phylogeny in 6 temperate floras, constraints, niche conservatism, and adaptation. American Naturalist 146: 349-364.

OBESO JR (1993) Seed mass variation in the perennial herb Asphodelus albus: sources of variation and position effect. Oecologia 93: 571-575.

PERES CA \& MGMV ROOSMALEN (2002) Primate frugivory two species-rich Neotropical forests: implications for the demography of large-seeded plants in overhunted areas. In: Levey DJ, WR Silva \& M Galetti (eds) Seed dispersal and frugivory: ecology, evolution and conservation: 407-421. CABI Publications, Wallingford, Oxon, United Kingdom

PIJL L VAN DER (1972) Principles of seed dispersal in higher plants. Second edition. Springer-Verlag, New York, New York, USA.
RIDLEY HN (1930) The dispersal of plants throughout the world. Reeve, Ashford, United Kingdom.

ROJAS AM (1997) Estructura de la comunidad y algunos aspectos ecológicos de los murciélagos del Parque Nacional Natural Tinigua. Tesis de pregrado, Universidad de Los Andes, Bogotá, Colombia. Xx-pp

ROOSMALEN MGM (1985) Fruits of the Guianan flora. Institute of Systematic Botany Utrecht University; Silvicultural Department of Wageningen Agricultural University, Wageningen, The Netherlands. $\mathrm{xl}+483 \mathrm{pp}$.

SCHUPP EW (1995) Seed-seedling conflicts, habitat choice, and patterns of plant recruitment. American Journal of Botany 82: 399-409.

SOKAL RR \& FJ ROHLF (1995) Biometry. Third edition. W.H. Freeman and Company, New York, New York, USA. xix + $887 \mathrm{pp}$.

STEVENSON PR (1996) Censos diurnos de mamíferos y algunas aves de gran tamaño en el Parque Nacional Tinigua, Colombia. Universitas Scientiarum 3: 67-81.

STEVENSON PR (2002) Frugivory and seed dispersal by woolly monkey (Lagothrix lagothricha) at Tinigua National Park, Colombia. Ph.D thesis, State University of New York at Stony Brook, New York, USA. xvi+417 pp.

STEVENSON PR, MJ QUIÑONES \& JA AHUMADA (1994) Ecological strategies of woolly monkeys (Lagothrix lagotricha) at La Macarena, Colombia. American Journal of Primatology 32: 123-140.

STEVENSON PR, MJ QUIÑONES \& MC CASTELLANOS (2000) Guía de frutos de los bosques del Río Duda, La Macarena, Colombia. International Union for Conservation of Nature (The Netherlands) and Asociación para la Defensa de La Macarena, Bogotá, Colombia. 467 pp.

TERBORGH J (1983) Five New World Primates. A study on comparative ecology. Princeton University Press, Princeton, New Jersey, USA. xiv + 260 pp.

TERBORGH J, SK ROBINSON, TA PARKER, CA MUNN \& N PIERPONT (1990) Structure and organization of an Amazonian forest bird community. Ecological Monographs 60: 213-238.

THOMPSON JN (1994) The coevolutionary process. The University of Chicago Press, Chicago, Illinois, USA. xi + $376 \mathrm{pp}$

VOSS RS \& LH EMMONS (1996) Mammalian diversity in Neotropical lowland rainforests: a preliminary assessment. Bulletin of the American Museum of Natural History: 3-115.

WHEELWRIGHT NT (1985) Fruit size, gape width, and the diets of fruit-eating birds. Ecology 66: 808-818.

WHEELWRIGHT NT (1988) Four constraints in coevolution between fruit-eating birds and fruiting plants: a tropical case study. In: Oullet $\mathrm{H}$ (ed) Acta XIX Congressus Internationalis Ornithologici: 827 845. Ottawa University Press, Ottawa, Canada.

WITMER MC \& AS CHEKE (1991) The dodo and the tambalacoque tree - an obligate mutualism reconsidered. Oikos 61: 133-137. 


\section{APPENDIX 1}

Animal dispersed plant species in Tinigua National Park, that were included in the analyses of dispersal syndromes. The columns show the morphological traits for each plant species. Fruit size refers to the largest dimension of the fruit (width or length)

Listado de las especies de plantas del Parque Nacional Tinigua que fueron incluidas en el análisis de síndromes de dispersión de frutos. Las columnas muestran los caracteres morfológicos de cada especie. El tamaño de los frutos hace referencia a la dimensión mas grande (entre largo y ancho del fruto)

\begin{tabular}{|c|c|c|c|}
\hline Species & Fruit size (mm) & Color & Protection \\
\hline Gnetum nodiflorum & 27.5 & Red & No \\
\hline Anthurium clavigerum & 4 & Blue/purple & No \\
\hline Anthurium eminens & 7.5 & Blue/purple & No \\
\hline Anthurium fendleri & 5 & Blue/purple & No \\
\hline Anthurium kunthii & 5 & Blue/purple & No \\
\hline Anthurium cf. superbum & 5 & Blue/purple & No \\
\hline Anthurium gracile & 3 & Red & No \\
\hline Caladium bicolor & 3 & Yellow & No \\
\hline Dieffenbachia longispatha & 6.5 & Red & No \\
\hline Dieffenbachia cf. parlatoii & 6.5 & Red & No \\
\hline Dracontium sp. & 6 & Orange & No \\
\hline Monstera adansonii & 12.5 & White & No \\
\hline Monstera dilacerata & 12.5 & White & No \\
\hline Monstera lechleriana & 5.5 & White & No \\
\hline Monstera gracilis & 6 & Yellow & No \\
\hline Philodendron sp. & 3 & Yellow & No \\
\hline Philodendron divaricatum & 3.5 & Yellow & No \\
\hline Philodendron ernestii & 2.3 & Yellow & No \\
\hline Philodendron fragrantissimum & 5.5 & Red & No \\
\hline Philodendron cf cuneatum & 2.5 & White & No \\
\hline Spathiphyllum cannaefolium & 15.6 & Green & No \\
\hline Syngonium podophyllum & 30 & Yellow & Yes \\
\hline Syngonium yurimaguense & 34 & Yellow & Yes \\
\hline Aiphanes aculeata & 22.5 & Red & No \\
\hline Attalea insignis & 50 & Brown & No \\
\hline Astrocaryum chambira & 47.5 & Yellow & No \\
\hline Bactris corossilla & 20.5 & Blue/purple & No \\
\hline Bactris macana & 24 & Red & No \\
\hline Bactris maraja & 17.5 & Black & No \\
\hline Euterpe precatoria & 11.5 & Black & No \\
\hline Geonoma macrostachya & 8 & Black & No \\
\hline Geonoma interrupta & 5 & Black & No \\
\hline Iriartea deltoidea & 34 & Mixed & No \\
\hline Oenocarpus bataua & 45 & Mixed & No \\
\hline Oenocarpus mapora & 11.5 & Mixed & No \\
\hline Socratea exorrhiza & 22.5 & Mixed & No \\
\hline Syagrus sancona & 24 & Orange & No \\
\hline Aechmea rubiginosa & 24 & Yellow & Yes \\
\hline Araeococcus flagellifolius & 10 & Mixed & No \\
\hline Dichorisandra cf. aequatorialis & 6 & Mixed & No \\
\hline Dichorisandra hexandra & 6 & Mixed & No \\
\hline Dichorisandra villosula & 12 & Blue/purple & No \\
\hline Tradescantia zanonia & 4 & Blue/purple & No \\
\hline Costus guianensis & 20 & Mixed & No \\
\hline Costus scaber & 17.5 & Mixed & No \\
\hline Costus spiralis & 17.5 & Mixed & No \\
\hline Dimerocostus strobilaceus & 11.5 & Brown & No \\
\hline Asplundia moritziana & 15 & Green & Yes \\
\hline Carludovica palmata & 9 & Red & No \\
\hline Cyclanthus bipartitus & & Green & No \\
\hline Xiphidium caeruleum & 4 & Red & No \\
\hline Heliconia episcopalis & 8 & Mixed & No \\
\hline Heliconia hirsuta & 10 & Mixed & No \\
\hline Heliconia latispatha & 10 & Mixed & No \\
\hline Heliconia marginata & 10 & Mixed & No \\
\hline Heliconia rostrata & 8.5 & Mixed & No \\
\hline Heliconia spathocircinata & 9 & Mixed & No \\
\hline
\end{tabular}




\begin{tabular}{|c|c|c|c|}
\hline Species & Fruit size $(\mathrm{mm})$ & Color & Protection \\
\hline Heliconia stricta & 15 & Mixed & No \\
\hline Eucharis ulei & 10 & Mixed & No \\
\hline Calathea inocephala & 9 & Mixed & No \\
\hline Pleiostachya pruinosa & 8.5 & Mixed & No \\
\hline Smilax aequatorialis & 16 & Orange & No \\
\hline Phenakospermum guyanense & 70 & Red & No \\
\hline Renealmia breviscapa & 6 & Mixed & No \\
\hline Renealmia cernua & 7 & Mixed & No \\
\hline Antrocaryon amazonica & 26 & Yellow & No \\
\hline Spondias mombin & 25 & Yellow & No \\
\hline Spondias venulosa & 25 & Yellow & No \\
\hline Tapirira guianensis & 7.5 & Yellow & No \\
\hline Annona sp. & 55 & Yellow & No \\
\hline Duguetia quitarensis & 115 & Red & Yes \\
\hline Guatteria punctata & 5.5 & Blue/purple & No \\
\hline Malmea sp. & 14 & Blue/purple & Yes \\
\hline Oxandra mediocris & 7.5 & Blue/purple & No \\
\hline Rollinia edulis & 50 & Green & Yes \\
\hline Ruizodendron ovale & 17.5 & Black & No \\
\hline Unonopsis cf. guatterioides & 14 & Green & No \\
\hline Xylopia amazonica & 8 & Red & No \\
\hline Pacouria guianensis & 140 & Yellow & Yes \\
\hline Stemmadenia grandiflora & 14 & Mixed & No \\
\hline Tabernaemontana heterophylla & 12 & Mixed & No \\
\hline Tabernaemontana sananho & 15 & Mixed & No \\
\hline Dendropanax caucanus & 10 & Black & No \\
\hline Schefflera morototoni & 7.5 & Black & No \\
\hline Sciadodendron excelsum & 8.5 & Black & No \\
\hline Bixa urucurana & 18 & Mixed & No \\
\hline Pachira orinocensis & 25 & Green & No \\
\hline Quararibea cf. wittii & 22.5 & Orange & No \\
\hline Cordia bicolor & 8.5 & Green & No \\
\hline Cordia bifurcata & 4 & Red & No \\
\hline Cordia nodosa & 11 & White & No \\
\hline Cordia cf ripicola & 14 & Black & No \\
\hline Tournefortia foetidissima & 6 & White & No \\
\hline Bursera inversa & 8.5 & Blue/purple & No \\
\hline Crepidospermum goudotianum & 5 & Red & No \\
\hline Crepidospermum rhoifolium & 11 & Orange & No \\
\hline Dacryodes sp. & 19 & Black & No \\
\hline Protium aracouchini & 8.5 & Mixed & No \\
\hline Protium crenatum & 11 & Mixed & No \\
\hline Protium glabrescens & 10 & Mixed & No \\
\hline Protium robustum & 17 & Mixed & No \\
\hline Protium sagotianum & 22 & Mixed & No \\
\hline Trattinnickia rhoifolia & 8.5 & Black & No \\
\hline Epiphyllum phyllanthus & 35 & Red & No \\
\hline Hylocereus polyrhizus & 75 & Red & No \\
\hline Pereskia aculeata & 26.5 & Yellow & No \\
\hline Pereskia bleo & 45 & Yellow & No \\
\hline Disocactus sp. & 6 & White & No \\
\hline Rhipsalis baccifera & 5 & White & No \\
\hline Dialium guianense & 6.5 & Brown & Yes \\
\hline Hymenaea courbaril & 60 & Brown & Yes \\
\hline Hymenaea oblongifolia & 25.5 & Brown & Yes \\
\hline Capparis detonsa & 20 & Green & No \\
\hline Capparis frondosa & 11 & Blue/purple & No \\
\hline Crateva tapia & 62.5 & Yellow & Yes \\
\hline Carica cf. goudotianum & 40 & Orange & Yes \\
\hline Jacaratia digitata & 45 & Orange & No \\
\hline Cecropia engleriana & 10 & Green & No \\
\hline Cecropia ficifolia & 10 & Green & No \\
\hline Cecropia membranacea & 9.5 & Green & No \\
\hline Cecropia sciadophylla & 15 & Yellow & No \\
\hline Coussapoa asperifolia & 14 & Red & No \\
\hline Coussapoa orthoneura & 7 & Red & No \\
\hline Coussapoa villosa & 23 & Mixed & No \\
\hline Pourouma bicolor & 11.5 & Blue/purple & Yes \\
\hline
\end{tabular}




\begin{tabular}{|c|c|c|c|}
\hline Species & Fruit size $(\mathrm{mm})$ & Color & Protection \\
\hline Pourouma minor & 14 & Blue/purple & No \\
\hline Pourouma mollis triloba & 11.5 & Blue/purple & Yes \\
\hline Pourouma petiolulata & 11.5 & Blue/purple & Yes \\
\hline Maytenus macrocarpa & 10 & Mixed & No \\
\hline Hirtella americana & 11.5 & Black & No \\
\hline Licania cf. arborea & 20 & Green & No \\
\hline Licania kunthiana & 9.5 & White & No \\
\hline Licania subarachnophylla & 27.5 & Brown & No \\
\hline Chrysochlamys aff membranacea & 4 & Mixed & No \\
\hline Clusia grandiflora & 9 & Mixed & No \\
\hline Clusia nigrolineata & 6 & Mixed & No \\
\hline Clusia palmicida & 6 & Mixed & No \\
\hline Clusia renggeroides & 5 & Mixed & No \\
\hline Clusiella sp. & 5 & Mixed & No \\
\hline Garcinia macrophylla & 50 & Yellow & Yes \\
\hline Garcinia madruno & 32.5 & Yellow & Yes \\
\hline Buchenavia capitata & 10.5 & Yellow & No \\
\hline Cnestidium rufescens & 6 & Mixed & No \\
\hline Connarus punctatus & 10 & Mixed & No \\
\hline Rourea glabra & 4 & Mixed & No \\
\hline Maripa cf. axilliflora & 18 & Yellow & Yes \\
\hline Maripa peruviana & 14 & Yellow & Yes \\
\hline Calycophysum cf. pedunculatum & 65 & Orange & Yes \\
\hline Cayaponia capitata & 50 & Red & Yes \\
\hline Cayaponia ophtalmica & 25 & Red & No \\
\hline Cayaponia cf. ruizii & 24 & Blue/purple & No \\
\hline Cayaponia granatensis & 19 & Blue/purple & No \\
\hline Gurania eriantha & 20.8 & Green & Yes \\
\hline Gurania cf. macrantha & 20.8 & Green & Yes \\
\hline Gurania pedata & 20.8 & Green & Yes \\
\hline Gurania rizantha & 20.8 & Green & Yes \\
\hline Melothria dulcis & 30 & Yellow & Yes \\
\hline Psiguria triphylla & 25 & Green & Yes \\
\hline Sicydium diffusum & 7 & Black & No \\
\hline Dichapetalum spruceanum & 15 & Black & No \\
\hline Tapura acreana & 10 & Green & No \\
\hline Davilla nitida & 5 & Red & No \\
\hline Davilla rugosa & 5 & Blue/purple & No \\
\hline Doliocarpus multiflorus & 9 & Blue/purple & No \\
\hline Tetracera willdenowiana & 3 & Mixed & No \\
\hline Diospyros artanthifolia & 30 & Yellow & Yes \\
\hline Muntingia calabura & 12.5 & Red & No \\
\hline Sloanea guianensis & 8 & Red & No \\
\hline Alchornea glandulosa & 8.5 & Red & No \\
\hline Caryodendron orinocense & 45 & Green & No \\
\hline Drypetes amazonica & 10.5 & Green & No \\
\hline Hyeronima alchorneoides & 4.5 & Blue/purple & No \\
\hline Hyeronima oblonga & 3.5 & Blue/purple & No \\
\hline Margaritaria nobilis & 4 & Blue/purple & No \\
\hline Omphalea diandra & 90 & Green & Yes \\
\hline Pera arborea & 5 & Mixed & No \\
\hline Pera benensis & 5 & Mixed & No \\
\hline Plukenetia polyadenia & 19 & Green & Yes \\
\hline Sapium glandulosum & 6 & Mixed & No \\
\hline Apium laurifolium & 5 & Mixed & No \\
\hline Sapium marmieri & 6 & Mixed & No \\
\hline Andira inermis & 50 & Green & No \\
\hline Dipteryx micrantha & 29.5 & Yellow & No \\
\hline Swartzia arborescens & 20 & Green & Yes \\
\hline Swartzia cardiosperma & 13 & Green & Yes \\
\hline Swartzia leptopetala & 16 & Green & Yes \\
\hline Swartzia trianae & 22 & Green & Yes \\
\hline Casearia aculeata & 3 & Red & No \\
\hline Laetia corymbulosa & 7 & Mixed & No \\
\hline Laetia procera & 4 & Mixed & No \\
\hline Lindackeria paludosa & 8 & Mixed & No \\
\hline Mayna odorata & 20 & Yellow & Yes \\
\hline Drymonia serrulata & 12 & Mixed & No \\
\hline
\end{tabular}




\begin{tabular}{|c|c|c|c|}
\hline Species & Fruit size $(\mathrm{mm})$ & Color & Protection \\
\hline Salacia macrantha & 37.5 & Yellow & Yes \\
\hline Tontelea attenuata & 20 & Yellow & Yes \\
\hline Tontelea sp. & 20 & Yellow & Yes \\
\hline Aniba hostmanniana & 12.5 & Mixed & No \\
\hline Endlicheria krukovii & 19 & Mixed & No \\
\hline Endlicheria sericea & 17.5 & Mixed & No \\
\hline Nectandra membranacea & 12 & Green & No \\
\hline Ocotea sp. & 7 & Mixed & No \\
\hline Ocotea cernua & 7.5 & Mixed & No \\
\hline Ocotea longifolia & 7 & Mixed & No \\
\hline Ocotea oblonga & 14.5 & Mixed & No \\
\hline Ocotea tomentosa & 8 & Green & No \\
\hline Ocotea cf. amazonica & 10 & Green & No \\
\hline Ocotea floribunda & 12.5 & Black & No \\
\hline Rhodostemonodaphne kunthiana & 15 & Mixed & No \\
\hline Rhodostemonodaphne synandra & 15 & Mixed & No \\
\hline Couroupita guianensis & 200 & Brown & Yes \\
\hline Eschweilera andina & 80 & Brown & No \\
\hline Grias peruviana & 55 & Brown & No \\
\hline Gustavia hexapetala & 47.5 & Orange & Yes \\
\hline Gustavia poeppigiana & 50 & Green & Yes \\
\hline Strychnos schultesiana & 90 & Yellow & Yes \\
\hline Phthirusa retrofelxa & 5 & Red & No \\
\hline Psittacanthus cucullaris & 11.5 & Red & No \\
\hline Struthanthus orbicularis & 3.5 & Blue/purple & No \\
\hline Adenaria floribunda & 3 & Blue/purple & No \\
\hline Byrsonima crispa & 9.5 & Yellow & No \\
\hline Byrsonima cf. japurensis & 9.5 & Yellow & No \\
\hline Marcgravia macrophylla & 10 & Mixed & No \\
\hline Norantea guianensis & 9 & Mixed & No \\
\hline Souroubea sympetala & 10 & Mixed & No \\
\hline Bellucia grossularioides & 15 & Green & No \\
\hline Bellucia pentamera & 35 & Green & No \\
\hline Blakea rosea & 10 & Black & No \\
\hline Clidemia hirta & 8.5 & Blue/purple & No \\
\hline Clidemia inobsepta & 4 & Blue/purple & No \\
\hline Clidemia octona & 9.5 & Blue/purple & No \\
\hline Clidemia septuplinervia & 10 & Blue/purple & No \\
\hline Clidemia sp. & 13.5 & Blue/purple & No \\
\hline Henriettella fissanthera & 4 & Green & No \\
\hline Henriettella sylvestris & 5 & Green & No \\
\hline Leandra longicoma & 5 & Blue/purple & No \\
\hline Loreya strigosa & 11.5 & Green & No \\
\hline Miconia cf. affinis & 5.5 & Blue/purple & No \\
\hline Miconia elata & 4 & Blue/purple & No \\
\hline Miconia napoana & 8.5 & Blue/purple & No \\
\hline Miconia ampla & 7.5 & Yellow & No \\
\hline Miconia argyrophylla & 4.5 & Black & No \\
\hline Miconia cf. prasina & 4 & Black & No \\
\hline Miconia ternatifolia & 3 & Black & No \\
\hline Miconia dolichorryncha & 3.5 & Black & No \\
\hline Miconia erioclada & 7 & Black & No \\
\hline Miconia nervosa & 7 & Mixed & No \\
\hline Miconia trinervia & 4 & Mixed & No \\
\hline Guarea guidonia & 11 & Mixed & No \\
\hline Guarea kunthiana & 8 & Mixed & No \\
\hline Trichilia martiana & 8 & Mixed & No \\
\hline Trichilia maynasiana & 8 & Mixed & No \\
\hline Trichilia micrantha & 10 & Mixed & No \\
\hline Trichilia pallida & 7 & Mixed & No \\
\hline Trichilia cf. verrucosa & 15 & Mixed & No \\
\hline Trichilia pleeana & 7 & Mixed & No \\
\hline Trichilia tuberculata & 9 & Mixed & No \\
\hline Mendoncia lindavii & 13.5 & Blue/purple & No \\
\hline Mendoncia odorata & 13.5 & Blue/purple & No \\
\hline Abuta grandifolia & 12 & Yellow & Yes \\
\hline Abuta aff grandifolia & 12 & Yellow & Yes \\
\hline Cissampelos cf. tropaeolifolia & 5 & Red & No \\
\hline
\end{tabular}




\begin{tabular}{|c|c|c|c|}
\hline Species & Fruit size $(\mathrm{mm})$ & Color & Protection \\
\hline Disciphania ernstii & 2.1 & Blue/purple & No \\
\hline Odontocarya tripetala & 9 & Yellow & No \\
\hline Odontocarya mallosperma & 9 & Yellow & No \\
\hline Sciadotenia ramiflora & 7.5 & Green & No \\
\hline Sciadotenia toxifera & 17.5 & Green & No \\
\hline Abarema jupunba & 6 & Mixed & No \\
\hline Enterolobium cyclocarpum & 35 & Black & Yes \\
\hline Enterolobium schomburgkii & 17.5 & Black & No \\
\hline Inga cf acreana & 24 & Green & Yes \\
\hline Inga acuminata & 27.5 & Green & Yes \\
\hline Inga alba & 12.5 & Green & Yes \\
\hline Inga cylindrica & 25 & Green & Yes \\
\hline Inga brachyrhachys & 12.5 & Green & Yes \\
\hline Inga heterophylla & 17.5 & Green & Yes \\
\hline Inga densiflora & 12.5 & Green & Yes \\
\hline Inga edulis & 11.2 & Green & Yes \\
\hline Inga gracilior & 19 & Green & Yes \\
\hline Inga leiocalycina & 22.5 & Green & Yes \\
\hline Inga macrophylla & 30 & Green & Yes \\
\hline Inga sapindoides & 22.5 & Green & Yes \\
\hline Inga umbellifera & 20.5 & Green & Yes \\
\hline Inga marginata & 12.5 & Green & Yes \\
\hline Inga stenoptera & 25 & Green & Yes \\
\hline Inga tenuistipula & 28.5 & Green & Yes \\
\hline Inga acrocephala & 40 & Green & Yes \\
\hline Inga thibaudiana & 23 & Green & Yes \\
\hline Inga vera & 12.5 & Green & Yes \\
\hline Inga vismiifolia & 70 & Green & Yes \\
\hline Parkia multijuga & 70 & Black & Yes \\
\hline Samanea saman & 16.5 & Black & Yes \\
\hline Stryphnodendron guianense & 9.5 & Black & Yes \\
\hline Siparuna cf asperula & 3 & Red & No \\
\hline Siparuna gilgiana & 3 & Red & No \\
\hline Siparuna cervicornis & 3 & Blue/purple & No \\
\hline Siparuna cuspidata & 3 & Blue/purple & No \\
\hline Batocarpus amazonicus & 40 & Yellow & No \\
\hline Batocarpus orinocensis & 50 & Green & Yes \\
\hline Brosimum alicastrum & 20.5 & Yellow & No \\
\hline Brosimum guianense & 16.5 & Red & No \\
\hline Brosimum aff. lactescens & 15 & Blue/purple & No \\
\hline Brosimum lactescens & 15 & Orange & No \\
\hline Brosimum utile & 16 & Green & No \\
\hline Castilla ulei & 30 & Yellow & Yes \\
\hline Clarisia biflora & 23 & Green & No \\
\hline Clarisia racemosa & 14.5 & Red & No \\
\hline Dorstenia contrajerva & 25 & Green & No \\
\hline Ficus americana & 9 & Red & No \\
\hline Ficus andicola & 6 & Red & No \\
\hline Ficus donnell-smithii & 8 & Red & No \\
\hline Ficus guianensis & 6.5 & Red & No \\
\hline Ficus pertusa & 6 & Red & No \\
\hline Ficus sphenophylla & 6.5 & Red & No \\
\hline Ficus trigona & 9.5 & Red & No \\
\hline Ficus gomelleira & 17 & Green & No \\
\hline Ficus insipida & 31.5 & Green & Yes \\
\hline Ficus maxima & 32.5 & Green & No \\
\hline Ficus membranacea & 22.5 & Green & No \\
\hline Ficus nymphaeifolia & 23 & Green & No \\
\hline Ficus obtusifolia & 24 & Green & No \\
\hline Ficus paraensis & 16 & Green & No \\
\hline Ficus schultesii & 25 & Green & No \\
\hline Ficus trigonata comp maximiliana & 25 & Green & No \\
\hline Ficus trigonata comp trigonata & 27.5 & Green & No \\
\hline Ficus usiacurina & 20 & Green & No \\
\hline Ficus yoponensis & 15 & Green & No \\
\hline Ficus sp. 2126 & 19 & Green & No \\
\hline Helicostylis tomentosa & 25 & Yellow & No \\
\hline Maquira calophylla & 22.5 & Yellow & Yes \\
\hline
\end{tabular}




\begin{tabular}{|c|c|c|c|}
\hline Species & Fruit size $(\mathrm{mm})$ & Color & Protection \\
\hline Perebea mollis & 24 & Yellow & No \\
\hline Perebea xanthochyma & 4.5 & Red & No \\
\hline Pseudolmedia laevigata & 7.5 & Red & No \\
\hline Pseudolmedia laevis & 8 & Red & No \\
\hline Pseudolmedia obliqua & 14 & Yellow & No \\
\hline Sorocea briquetii & 6.5 & Blue/purple & No \\
\hline Sorocea steinbachii & 10 & Blue/purple & No \\
\hline Trophis racemosa & 7 & Red & No \\
\hline Iryanthera juruensis & 13 & Mixed & No \\
\hline Iryanthera leavis & 19 & Mixed & No \\
\hline Virola calophylla & 11 & Mixed & No \\
\hline Virola cf. cariniata & 12 & Mixed & No \\
\hline Virola cf elongata & 10 & Mixed & No \\
\hline Virola flexuosa & 12 & Mixed & No \\
\hline Virola multinervia & 12 & Mixed & No \\
\hline Virola peruviana & 13 & Mixed & No \\
\hline Virola sebifera & 10 & Mixed & No \\
\hline Ardisia panurensis & 4 & Blue/purple & No \\
\hline Ardisia pellucida & 6.5 & Blue/purple & No \\
\hline Stylogyne turbacensis & 8 & Mixed & No \\
\hline Cатротапеsia speciosa & 30 & Brown & Yes \\
\hline Eugenia biflora & 6 & Blue/purple & No \\
\hline Eugenia florida & 12.5 & Red & No \\
\hline Eugenia nesiotica & 24.5 & Red & No \\
\hline Eugenia stipitata & 45 & Yellow & No \\
\hline Eugenia lambertiana & 8.5 & Yellow & No \\
\hline Guapira cf cuspidata & 10 & Red & No \\
\hline Guapira olfersiana & 8.5 & Black & No \\
\hline Neea laxa & 8 & Mixed & No \\
\hline Neea cf divaricata & 6.5 & Blue/purple & No \\
\hline Neea verticillata & 10.5 & Black & No \\
\hline Ouratea cf polyantha & 6 & Mixed & No \\
\hline Ouratea weberbaueri & 7.5 & Mixed & No \\
\hline Heisteria acuminata & 7 & Mixed & No \\
\hline Heisteria nitida & 11 & Mixed & No \\
\hline Passiflora ambigua & 55 & Yellow & Yes \\
\hline Passiflora cf. micropetala & 21 & Black & Yes \\
\hline Passiflora vitifolia & 55 & Green & Yes \\
\hline Phytolacca rivinoides & 4 & Mixed & No \\
\hline Trichostigma octandrum & 6.5 & Mixed & No \\
\hline Peperomia laxiflora & 1 & Green & No \\
\hline Peperomia magnoliifolia & 5 & Green & No \\
\hline Peperomia rotundifolia & 1 & Green & No \\
\hline Peperomia serpens & 1 & Green & No \\
\hline Piper aduncum & 5 & Green & No \\
\hline Piper aequale & 5 & Green & No \\
\hline Piper arboreum & 5 & Green & No \\
\hline Piper cf. avellanum & 4 & Green & No \\
\hline Piper cumanense & 3 & White & No \\
\hline Piper demeraranum & 7 & Breen & No \\
\hline Piper fresnoense & 4 & Breen & No \\
\hline Piper hispidum & 5 & Breen & No \\
\hline Piper laevigatum & 3 & Breen & No \\
\hline Piper peltata & 5 & Breen & No \\
\hline Piper phytolaccaefolium & 4 & Green & No \\
\hline Coccoloba densifrons & 13.5 & Black & No \\
\hline Coccoloba coronata & 7.5 & Blue/purple & No \\
\hline Coccoloba mollis & 11.5 & Blue/purple & No \\
\hline Coccoloba cf. parimensis & 7.5 & Blue/purple & No \\
\hline Quiina macrophylla & 7.5 & Red & No \\
\hline Prunus myrtifolia & 10.2 & Blue/purple & No \\
\hline Alibertia cf hadrantha & 30 & Black & No \\
\hline Bertiera guianensis & 4.5 & Black & No \\
\hline Duroia hirsuta & 25 & Yellow & Yes \\
\hline Genipa americana & 80 & Brown & Yes \\
\hline Genipa cf. williamsii & 60 & Brown & Yes \\
\hline Geophila cordifolia & 4 & Red & No \\
\hline Geophila repens & 5 & Red & No \\
\hline
\end{tabular}




\begin{tabular}{|c|c|c|c|}
\hline Species & Fruit size $(\mathrm{mm})$ & Color & Protection \\
\hline Geophila macropoda & 10 & Black & No \\
\hline Gonzalagunia cornifolia & 6 & White & No \\
\hline Guettarda aromatica & 11 & Black & No \\
\hline Hamelia axillaris & 7.5 & Black & No \\
\hline Isertia leavis & 8.5 & Green & No \\
\hline Posoqueria longiflora & 35 & Yellow & Yes \\
\hline Psychotria bahiensis & 7.5 & Blue/purple & No \\
\hline Psychotria bracteocardia & 5 & Blue/purple & No \\
\hline Psychotria caerulea & 8.5 & Blue/purple & No \\
\hline Psychotria casiquiaria & 4.5 & Blue/purple & No \\
\hline Psychotria deflexa & 9 & Blue/purple & No \\
\hline Psychotria herzogii & 10 & Blue/purple & No \\
\hline Psychotria racemosa & 4.5 & Black & No \\
\hline Psychotria psychotriifolia & 7.5 & Red & No \\
\hline Psychotria muscosa & 5 & Red & No \\
\hline Psychotria tenuifolia & 6 & Red & No \\
\hline Psychotria viridis & 6 & Red & No \\
\hline Psychotria poeppigiana & 7 & Mixed & No \\
\hline Randia hondensis & 20.5 & Yellow & Yes \\
\hline Rudgea cornifolia & 7.5 & White & No \\
\hline Sabicea villosa & 8 & Blue/purple & No \\
\hline Cupania cinerea & 8 & Mixed & No \\
\hline Cupania cf. latifolia & 8 & Mixed & No \\
\hline Cupania pallida & 9 & Mixed & No \\
\hline Cupania scrobiculata & 6 & Mixed & No \\
\hline Paullinia alata & 8 & Mixed & No \\
\hline Paullinia bracteosa & 8 & Mixed & No \\
\hline Paullinia faginea & 7 & Mixed & No \\
\hline Paullinia grandifolia & 10 & Mixed & No \\
\hline Paullinia hispida & 7 & Mixed & No \\
\hline Paullinia obovata & 9 & Mixed & No \\
\hline Paullinia rugosa & 8 & Mixed & No \\
\hline Paullinia serjaniifolia & 6 & Mixed & No \\
\hline Paullinia sp. & 9 & Mixed & No \\
\hline Talisia intermedia & 22 & Yellow & Yes \\
\hline Talisia cf. nervosa & 20 & Red & Yes \\
\hline Vouarana guianensis & 10 & Mixed & No \\
\hline Chrysophyllum argenteum & 22 & Green & No \\
\hline Chrysophyllum cf lucentifolium & 45 & Yellow & No \\
\hline Chrysophyllum sp. & 27.5 & Yellow & No \\
\hline Chrysophyllum parvulum & 10 & Blue/purple & No \\
\hline Pouteria caimito & 25 & Yellow & Yes \\
\hline Pouteria cuspidata & 22.5 & Yellow & Yes \\
\hline Pouteria lucuma & 85 & Yellow & No \\
\hline Pouteria pariry & 100 & Yellow & No \\
\hline Pouteria procera & 37.5 & Yellow & Yes \\
\hline Pouteria reticulata & 13.5 & Blue/purple & Yes \\
\hline Pouteria sp. & 35 & Brown & Yes \\
\hline Sarcaulus brasiliensis & 22.5 & Yellow & Yes \\
\hline Picramnia latifolia & 5.5 & Red & No \\
\hline Simarouba amara & 10 & Black & No \\
\hline Brunfelsia grandiflora & 13.5 & Green & No \\
\hline Cestrum racemosum & 4 & Black & No \\
\hline Cestrum sylvaticum & 5 & Black & No \\
\hline Lycianthes cyathocalyx & 6.5 & Red & No \\
\hline Lycianthes pauciflora & 12.5 & Red & No \\
\hline Solanum cyathophorum & 6.5 & Black & No \\
\hline olanum grandiflorum & 47.5 & Black & No \\
\hline Solanum lepidotum & 8.5 & Black & No \\
\hline Solanum pectinatum & 48.2 & Black & No \\
\hline Solanum jamaicense & 7.5 & Red & No \\
\hline Solanum cf. americanum & & Red & No \\
\hline Solanum cf. sessile & 12 & Red & No \\
\hline Solanum sessiliflorum & 31.6 & Red & No \\
\hline Solanum sp. 2125 & 11 & Green & No \\
\hline Witheringia solanaceae & 7 & Red & No \\
\hline Guazuma ulmifolia & 13 & Black & No \\
\hline Herrania nitida & 50 & Green & Yes \\
\hline
\end{tabular}




\begin{tabular}{|c|c|c|c|}
\hline Species & Fruit size $(\mathrm{mm})$ & Color & Protection \\
\hline Sterculia apetala & 15 & Brown & No \\
\hline Sterculia guapayensis & 20 & Brown & No \\
\hline Sterculia colombiana & 15 & Mixed & No \\
\hline Theobroma cacao & 80 & Yellow & Yes \\
\hline Theobroma glaucum & 80 & Green & Yes \\
\hline Theobroma subincanum & 85 & Brown & Yes \\
\hline Clavija ornata & 21.5 & Yellow & Yes \\
\hline Apeiba aspera & 30 & Black & Yes \\
\hline Apeiba tibourbou & 37.5 & Black & Yes \\
\hline Ampelocera edentula & 18 & Yellow & No \\
\hline Celtis schippii & 9 & Black & No \\
\hline Celtis iguanaeus & 10 & Yellow & No \\
\hline Trema integerrima & 3 & Red & No \\
\hline Trema micrantha & 3 & Red & Yes \\
\hline Urera baccifera & 3 & Yellow & No \\
\hline Urera caracasana & 8.5 & White & No \\
\hline Aegiphila guianensis & 4.5 & Blue/purple & No \\
\hline Aegiphila integrifolia & 4.5 & Blue/purple & No \\
\hline Citharexylum spinosum & 6.5 & Black & No \\
\hline Vitex compressa & 20 & Green & No \\
\hline Vitex orinocensis & 12.5 & Blue/purple & No \\
\hline Leonia crassa & 52.5 & Brown & Yes \\
\hline Leonia glycycarpa & 52.5 & Brown & Yes \\
\hline Phoradendron piperoides & 4 & Red & No \\
\hline Cissus erosa & 7 & Blue/purple & No \\
\hline Cissus microcarpa & 11.5 & Black & No \\
\hline \multirow[t]{2}{*}{ Cissus sicyoides } & 7.5 & Black & No \\
\hline & age $=17.3$ & & \\
\hline
\end{tabular}

Associate Editor: Juan Armesto

Received October 21, 2002; accepted December 9, 2003 